\title{
Assessment of heavy metal pollution in groundwater with respect to distance from ash pond by using heavy metal evaluation index
}

\author{
Chanchal Verma ${ }^{1}\left(\mathbb{D} \cdot\right.$ Athar Hussain $^{2} \cdot$ Sangeeta Madan $^{1} \cdot$ Vinit Kumar $^{3}$
}

Received: 9 March 2019 / Accepted: 3 March 2021 / Published online: 17 March 2021

(c) The Author(s) 2021

\begin{abstract}
In order to assess the quality of groundwater near ash pond of Parichha Thermal Power Plant (Jhansi), heavy metal evaluation index (HEI)was calculated. An unlined ash pond is being used for a long time to dispose fly ash generated by thermal power plant. To assess the level of groundwater contamination due to ash slurry disposal, both groundwater and ash slurry samples were collected and analysed in terms of their chemical concentration. In the present study, it was observed that significant amount of trace elements can leach out from ash slurry and may contaminate groundwater due to downward percolation through soil strata in an unlined ash pond. Obtained results revealed the range of heavy metals concentration in groundwater as [Ni (0.02-0.07 mg/l), Pb (0.14-0.41 mg/l), Fe (0.20-7.21 mg/l), Mn (0.01-0.14 mg/l), Cr (0.03-0.05 mg/l) and $\mathrm{Al}(0.05-0.26 \mathrm{mg} / \mathrm{l})]$. HEI showed a heavy load of metal pollution within the range of $5 \mathrm{~km}$ from the ash pond while moderate pollution within the range of $7 \mathrm{~km}$ and very low at a distance of $15 \mathrm{~km}$.
\end{abstract}

Keywords Ash pond · Fly ash · Groundwater · Heavy metal evaluation index

\section{Introduction}

Fly ash disposal in an unlined ash pond may contaminate groundwater with heavy metals due to downward movement of leachate generated in ash pond (Theis and Gardner 1990; Carlson and Adriano 1993; Chanchal and Hussain 2014). When fly ash in slurry form is continuously disposed and accumulates for a long time in disposal site, it leads to percolation of leached heavy metals through soil profile and joins to groundwater (Mandal and Sengupta 2005; Chanchal and Hussain 2014). Therefore, inland disposal of fly ash is considered as major cause of groundwater contamination. Groundwater contamination due to leaching behaviour of fly ash has been given more concern because groundwater is more susceptible than surface water. Fly ash slurry in ash pond stands for a long time and land surface acts

Chanchal Verma

chanchalverma008@gmail.com

1 Department of Environmental Sciences, Gurukul Kangri University, Haridwar 249401, India

2 Civil Engineering Department, Gautam Buddha University, Greater Noida 201308, India

3 Institute of Environment and Development Studies, Bundelkhand University, Jhansi 284001, India as a filtering medium. Heavy metals leached from fly ash percolate through soil pores under low velocity and low permeability which lead to accumulation of heavy metals in groundwater. In this case, not only surface associated more soluble heavy metals get dissolved but the glassy particles of fly ash also dissolve and influence the groundwater quality (Choi et al. 2002).

The slurry and the ash pond water are found to be strongly alkaline with an average $\mathrm{pH}$ of 9.7 and TDS of $7290 \mathrm{mg} / \mathrm{l}$. The presence of $\mathrm{Al}$ and $\mathrm{Ca}$ in coal determines the $\mathrm{pH}$ and major ion chemistry of fly ash The ash leachate seeping from the base of the pond is expected to have similar chemistry but the exact concentration depends on a number of factors including the long-term leaching behaviour of ash, height and consolidation of final ash deposited (Mudd et al. 1998; Chanchal and Hussain 2014). The ash slurry water or leachate from ash pond gets percolated downward through the soil and joins groundwater table.

Thus, leachable metals enriched in fly ash deteriorate the water quality around the ash pond. Diurnal and seasonal variation enhances the leaching possibility of heavy metals in ash pond due to change in temperature, moisture and other parameters. This raises the potential threat of percolation of hazardous elements from fly ash to groundwater from the ash pond (Singh et al. 2014). Therefore, keeping the above 
facts in view, a heavy metal evaluation index has been developed to assess the deterioration level of groundwater around ash disposal site of Parichha Thermal Power Plant (Jhansi).

\section{Materials and methods}

\section{Study site}

Parichha thermal power station is situated at latitude of $25^{\circ}$ $52^{\prime} \mathrm{N}$ and longitude of $78^{\circ} 75^{\prime} \mathrm{E}$ in Jhansi district of Bundelkhand region, India. Thermal power plant is burning subbituminous type of coal. Fly ash produced due to combustion of coal is being disposed in an unlined ash pond by using wet disposal method, and the pond (ash lagoon) is situated at latitude and longitude of $25^{\circ} 30^{\prime} \mathrm{N}-78^{\circ} 46^{\prime} \mathrm{E}$. In order to quantify the groundwater contamination, villages in the range of 5-7 km of ash pond were selected as study area for the collection of groundwater sample (Fig. 1).

\section{Description of sampling locations, sampling procedure and analytical method}

Total numbers of eight sampling sites were selected for groundwater sampling. Sampling sites 1-7 were considered as study site which were located near the ash pond within the range of 5-7 km, while sampling site 8 was considered as control site, located at distance of $15 \mathrm{~km}$ from ash pond (Fig. 2). Sampling of groundwater was carried out from November 2017 to October 2018 on the monthly basis. Total number of 12 groundwater sampling was carried out throughout the study period. Groundwater sampling was carried out by using area sampling method. Three representative samples from bore wells of a particular nonoverlapping area (sampling sites) were collected. The depth of all bore wells lies in the range of 18-21 m. Groundwater samples were collected into prerinsed polypropylene bottles. Samples were preserved with nitric acid immediately on site for heavy metal analysis. Ash slurry disposed into ash pond was

Fig. 1 Map of study area
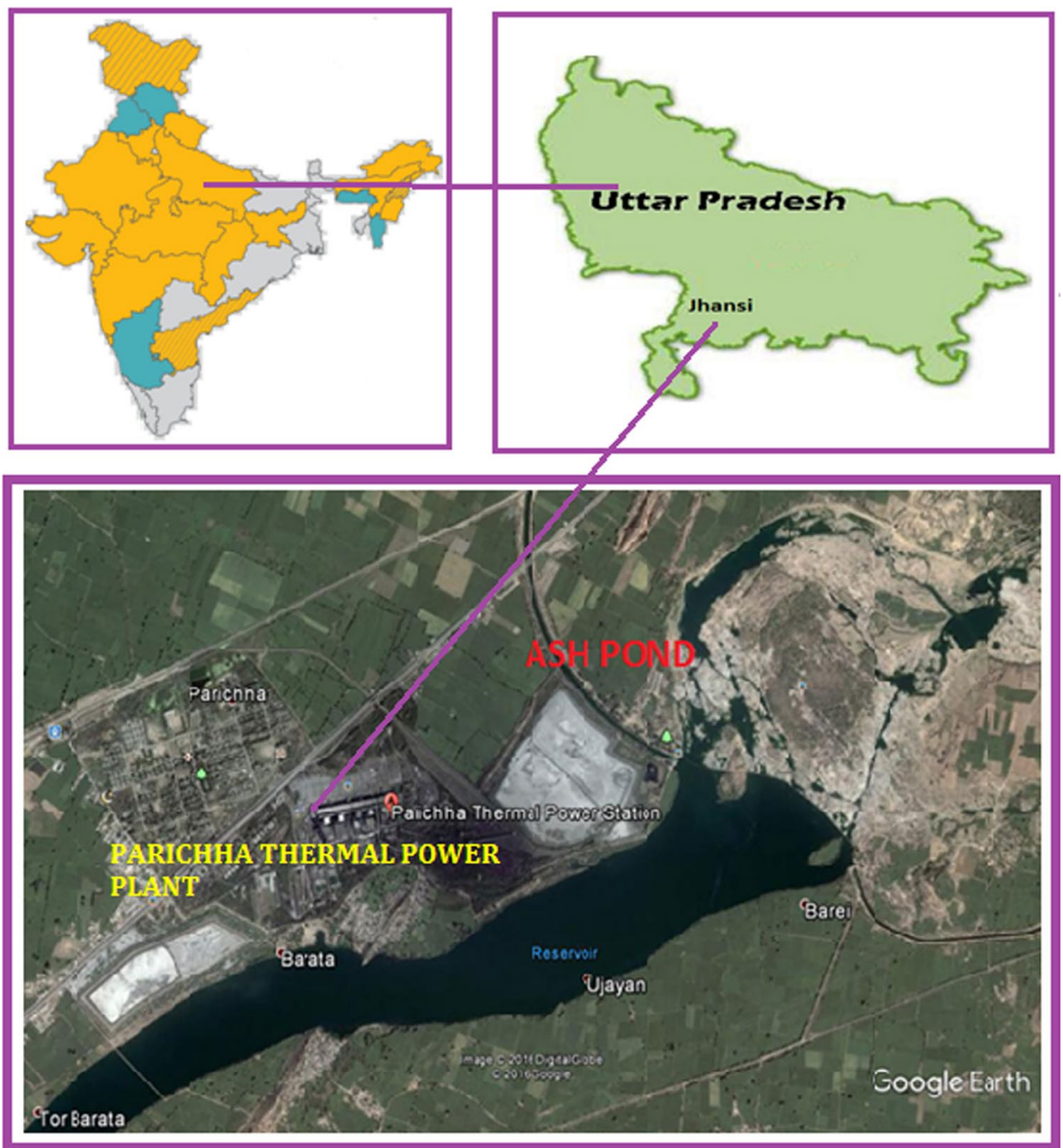


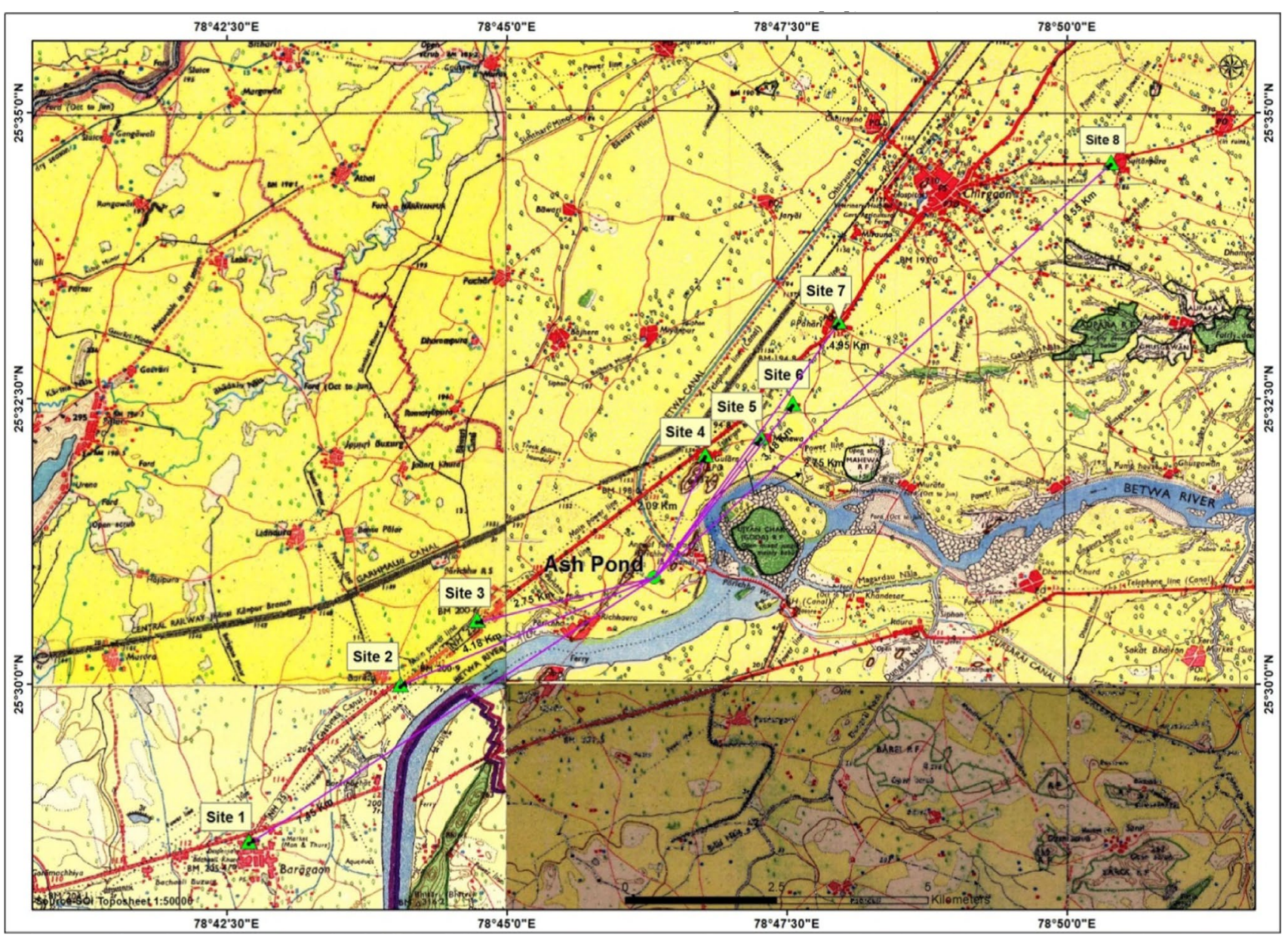

Fig. 2 Map showing groundwater sampling sites around ash pond of Parichha Thermal Power Plant

ment was calibrated with the standards of respective elements and the concentration of element was read in sample.

\section{Calculation of heavy metal evaluation index (HEI)}

Quality of water in terms of heavy metals can be quantified by using HEI method (Edet and Offiong 2002) and is computed as:

$\mathrm{HEI}=\sum_{i=1}^{n} \frac{H_{\mathrm{c}}}{H_{\mathrm{mac}}}$

where $H_{\mathrm{c}}$ is the monitored value of $i$ th parameter and $H_{\mathrm{mac}}$ the maximum admissible concentration of the $i$ th parameter.

Following the approach of Edet and Offiong (2002), the proposed HEI criteria for the samples are as follows: low $(\mathrm{HEI}<10)$, medium $(\mathrm{HEI}=10-20)$ and high $(\mathrm{HEI}>20)$ pollution zone.
$\mathrm{Cr}, \mathrm{Ba}, \mathrm{Ti}$ and $\mathrm{V}$ ) were found to be present in the ash slurry. The fresh ash slurry was found to be alkaline in nature. However, the ash pond decant was found to be slightly acidic in nature. Elements like $\mathrm{K}, \mathrm{Ca}, \mathrm{Mg}, \mathrm{Fe}, \mathrm{Ni}, \mathrm{Al}, \mathrm{Co}, \mathrm{Pb}, \mathrm{Si}$, $\mathrm{Mn}$ and $\mathrm{Ba}$ were found to be present in decant water but their concentrations were much less when compared with the chemical concentration in ash slurry, while in the filtrate of fresh ash slurry, the concentration of $\mathrm{Ca}, \mathrm{Mg}, \mathrm{K}$ and $\mathrm{Fe}$ was found to be negligible as compared to the ash slurry. Table 1 shows chemical composition of the ash slurry, filtrate and ash pond decant.

The obtained results revealed that the freshly disposed ash slurry does not leach. As the time increases, the weathering of fly ash takes place in aqueous media into the ash pond and leaching process starts with decrease in $\mathrm{pH}$. Different types of physicochemical reactions occurring in ash pond may change its $\mathrm{pH}$. Addition of rain water is another factor to decrease the $\mathrm{pH}$ of ash pond due to dissolution of atmospheric $\mathrm{CO}_{2}$ into it (Goodarzi 2006). It has also been recommended that aggressive environment and/or precipitation sorption reaction which is affected by $\mathrm{pH}$ is responsible 
for metal leachability (Kim et al. 2003). Fresh ash slurry is not able to affect the quality of the groundwater. Leaching of toxic elements progresses with respect to time, weathering of fly ash particles and decreased level of $\mathrm{pH}$ into ash pond.

\section{Heavy metal pollution level in groundwater near ash pond}

Considerable amount of heavy metals in groundwater was observed at different study sites near ash pond. Heavy metal concentration in groundwater is presented in Table 2. Nickel concentration in groundwater exceeded the prescribed limit of BIS $(0.02 \mathrm{mg} / \mathrm{l})$ at all sites (site 1-7) except at control site (site 8). Concentration of lead also exceeded the BIS limit $(0.01 \mathrm{mg} / \mathrm{l})$ at all the study sites located near the ash pond and at the control site but the values at site near the ash pond were much higher than the values at the control site. The higher value of lead at the control site may be due to vehicular pollution. Baba et al. (2003) have also reported the similar observation in their study in Mugla, Turkey. Iron was observed exceeding the limit at sites 4-7 and at all other sites was within the limit. The prescribed acceptable limit for manganese in drinking water is $0.1 \mathrm{mg} / \mathrm{l}$ (BIS 2012). The value of manganese in groundwater was found within this limit at all sites except at site 4-6. Similar values of iron and manganese in groundwater were also reported by Praharaj et al. (2002) during the study of leachability of elements from sub-bituminous coal fly ash from India. Barring the site 4 and 5 , chromium concentration in the groundwater was within the limit of BIS $(0.05 \mathrm{mg} / \mathrm{l})$, while its value in groundwater at sites located near the ash pond was much higher than the control site. Aluminium concentration in groundwater was observed only at site 3-5 and concentration was higher than BIS limit at all three sites.
Table 1 Chemical properties of hydraulic transport water

\begin{tabular}{lcll}
\hline & Ash slurry & Filtrate of ash slurry & Ash pond decant \\
\hline $\mathrm{pH}$ & $7.9 \pm 0.35$ & $7.7 \pm 0.49$ & $6.9 \pm 0.59$ \\
Electrical conductivity $(\mathrm{mS} / \mathrm{cm})$ & $0.41 \pm 0.19$ & $0.42 \pm 0.13$ & $0.74 \pm 0.29$ \\
Total dissolved solids $(\mathrm{mg} / \mathrm{l})$ & $445 \pm 39$ & $430 \pm 52$ & $610.98 \pm 30.17$ \\
Calcium $(\mathrm{mg} / \mathrm{l})$ & $340.38 \pm 85.29$ & $12.29 \pm 2.48$ & $154.48 \pm 22.35$ \\
Magnesium (mg/l) & $217.69 \pm 91.35$ & $1.35 \pm 0.12$ & $131.68 \pm 19.30$ \\
Potassium (mg/l) & $370.15 \pm 72.18$ & $1.94 \pm 0.23$ & $98.29 \pm 14.67$ \\
Aluminium (mg/l) & $8.25 \pm 1.14$ & BDL & $0.59 \pm 0.18$ \\
Silica $(\mathrm{mg} / \mathrm{l})$ & $4.31 \pm 0.98$ & BDL & $0.13 \pm 0.06$ \\
Iron $(\mathrm{mg} / \mathrm{l})$ & $22.68 \pm 3.17$ & $0.19 \pm 0.02$ & $1.5 \pm 0.27$ \\
Cobalt $(\mathrm{mg} / \mathrm{l})$ & $6.82 \pm 1.24$ & BDL & $0.82 \pm 0.13$ \\
Manganese (mg/l) & $2.39 \pm 0.74$ & BDL & $0.33 \pm 0.09$ \\
Nickel (mg/l) & $14.32 \pm 2.71$ & BDL & $0.74 \pm 0.24$ \\
Copper (mg/l) & $5.38 \pm 1.47$ & BDL & BDL \\
Lead (mg/l) & $4.19 \pm 0.81$ & BDL & $0.48 \pm 0.17$ \\
Zinc (mg/l) & $2.87 \pm 0.74$ & BDL & BDL \\
Chromium (mg/l) & $1.79 \pm 0.21$ & BDL & BDL \\
Barium (mg/l) & $15.68 \pm 1.79$ & BDL & $0.17 \pm 0.85$ \\
Titanium (mg/l) & $3.21 \pm 0.87$ & BDL & BDL \\
Vanadium (mg/l) & $2.08 \pm 0.53$ & BDL & BDL \\
\hline
\end{tabular}

Table 2 Heavy metal concentration in groundwater near ash pond

\begin{tabular}{llllllllll}
\hline $\begin{array}{l}\text { Heavy } \\
\text { metals } \\
(\mathrm{mg} / \mathrm{l})\end{array}$ & Site 1 & Site 2 & Site 3 & Site 4 & Site 5 & Site 6 & Site 7 & Site 8 & BIS (2012) \\
\hline $\mathrm{Ni}$ & $0.02 \pm 0.003$ & $0.05 \pm 0.006$ & $0.06 \pm 0.007$ & $0.07 \pm 0.011$ & $0.06 \pm 0.010$ & $0.07 \pm 0.005$ & $0.04 \pm 0.010$ & $0.01 \pm 0.002$ & 0.02 \\
$\mathrm{~Pb}$ & $0.14 \pm 0.028$ & $0.14 \pm 0.004$ & $0.20 \pm 0.033$ & $0.41 \pm 0.078$ & $0.37 \pm 0.079$ & $0.36 \pm 0.090$ & $0.27 \pm 0.050$ & $0.07 \pm 0.005$ & 0.01 \\
$\mathrm{Fe}$ & $0.20 \pm 0.026$ & $0.23 \pm 0.024$ & $0.24 \pm 0.030$ & $0.46 \pm 0.034$ & $7.21 \pm 1.500$ & $0.42 \pm 0.040$ & $0.63 \pm 0.090$ & $0.17 \pm 0.020$ & 0.3 \\
$\mathrm{Mn}$ & $0.02 \pm 0.01$ & $0.01 \pm 0.005$ & $0.02 \pm 0.010$ & $0.11 \pm 0.025$ & $0.14 \pm 0.030$ & $0.11 \pm 0.025$ & $0.06 \pm 0.015$ & $0.01 \pm 0.003$ & 0.1 \\
$\mathrm{Cr}$ & $0.03 \pm 0.002$ & $0.04 \pm 0.003$ & $0.04 \pm 0.004$ & $0.05 \pm 0.003$ & $0.05 \pm 0.002$ & $0.04 \pm 0.003$ & $0.04 \pm 0.003$ & $0.007 \pm 0.002$ & 0.05 \\
$\mathrm{Al}$ & $\mathrm{BDL}$ & $\mathrm{BDL}$ & $0.052 \pm 0.020$ & $0.64 \pm 0.090$ & $0.26 \pm 0.060$ & BDL & BDL & BDL & 0.2 \\
\hline
\end{tabular}


Table 3 Heavy metal evaluation index for groundwater at site 1

\begin{tabular}{lllcl}
\hline & Hc & Hmac & Hc/Hmac & HEI \\
\hline $\mathrm{Ni}$ & 0.02 & 0.02 & 1.32 & 17.12 \\
$\mathrm{~Pb}$ & 0.14 & 0.01 & 14.14 & \\
$\mathrm{Fe}$ & 0.20 & 0.3 & 0.68 & \\
$\mathrm{Mn}$ & 0.02 & 0.1 & 0.24 & \\
$\mathrm{Cr}$ & 0.03 & 0.05 & 0.73 & \\
\hline
\end{tabular}

Table 4 Heavy metal evaluation index for groundwater at site 2

\begin{tabular}{lllll}
\hline & Hc & Hmac & Hc/Hmac & HEI \\
\hline $\mathrm{Ni}$ & 0.05 & 0.02 & 2.80 & 19.43 \\
$\mathrm{~Pb}$ & 0.14 & 0.01 & 4.80 & \\
$\mathrm{Fe}$ & 0.23 & 0.3 & 0.77 & \\
$\mathrm{Mn}$ & 0.01 & 0.1 & 0.18 & \\
$\mathrm{Cr}$ & 0.04 & 0.05 & 0.86 & \\
\hline
\end{tabular}

Table 5 Heavy metal evaluation index for groundwater at site 3

\begin{tabular}{lllcl}
\hline & Hc & Hmac & Hc/Hmac & HEI \\
\hline $\mathrm{Ni}$ & 0.06 & 0.02 & 3.03 & 26.01 \\
$\mathrm{~Pb}$ & 0.20 & 0.01 & 20.76 & \\
$\mathrm{Fe}$ & 0.24 & 0.3 & 0.82 & \\
$\mathrm{Mn}$ & 0.02 & 0.1 & 0.25 & \\
$\mathrm{Cr}$ & 0.04 & 0.05 & 0.86 & \\
$\mathrm{Al}$ & 0.05 & 0.2 & 0.25 & \\
\hline
\end{tabular}

According to HEI given in Tables 3, 4, 5, 6, 7, 8, 9 and 10 , groundwater at control site showed low level of metal pollution. Site 1 and Site 2 were found to be receiving medium level of metal pollution. In case of sites 3-7, HEI indicated the heavy pollution load. HEI revealed that sites located $(7-15 \mathrm{~km})$ from ash pond showed less contamination effect. Kapoor and Christian (2016) have also reported the decreasing trend of pollution with increasing the distance from ash pond.

\section{Conclusion}

Referring the HEI values, it can be concluded that the quality of groundwater is more deteriorated at sites located near the ash pond. According to HEI, groundwater within the range of $5 \mathrm{~km}$ showed a heavy load of heavy metal pollution. Moderate level of metal pollution was observed in the range of $7 \mathrm{~km}$ and at a distance of $15 \mathrm{~km}$ heavy metal pollution was found to be very low. Thus, the groundwater quality at sampling sites near ash pond showed more deteriorated condition than sites located at a distance. Thus, on the basis
Table 6 Heavy metal evaluation index for groundwater at site 4

\begin{tabular}{lllcl}
\hline & Hc & Hmac & Hc/Hmac & HEI \\
\hline $\mathrm{Ni}$ & 0.07 & 0.02 & 3.545833 & 52.01764 \\
$\mathrm{~Pb}$ & 0.41 & 0.01 & 41.5625 & \\
$\mathrm{Fe}$ & 0.46 & 0.3 & 1.550556 & \\
$\mathrm{Mn}$ & 0.11 & 0.1 & 1.16125 & \\
$\mathrm{Cr}$ & 0.05 & 0.05 & 0.976667 & \\
$\mathrm{Al}$ & 0.64 & 0.2 & 3.220833 & \\
\hline
\end{tabular}

Table 7 Heavy metal evaluation index for groundwater at site 5

\begin{tabular}{lllcl}
\hline & Hc & Hmac & Hc/Hmac & HEI \\
\hline $\mathrm{Ni}$ & 0.06 & 0.02 & 3.32 & 68.44 \\
$\mathrm{~Pb}$ & 0.37 & 0.01 & 37.31 & \\
$\mathrm{Fe}$ & 7.21 & 0.3 & 24.03 & \\
$\mathrm{Mn}$ & 0.14 & 0.1 & 1.42 & \\
$\mathrm{Cr}$ & 0.05 & 0.05 & 1.02 & \\
$\mathrm{Al}$ & 0.26 & 0.2 & 1.30 & \\
\hline
\end{tabular}

Table 8 Heavy metal evaluation index for groundwater at site 6

\begin{tabular}{lllrl}
\hline & $\mathrm{Hc}$ & Hmac & Hc/Hmac & HEI \\
\hline $\mathrm{Ni}$ & 0.07 & 0.02 & 3.86 & 43.89 \\
$\mathrm{~Pb}$ & 0.36 & 0.01 & 36.51 & \\
$\mathrm{Fe}$ & 0.42 & 0.3 & 1.42 & \\
$\mathrm{Mn}$ & 0.11 & 0.1 & 1.17 & \\
$\mathrm{Cr}$ & 0.04 & 0.05 & 0.92 & \\
\hline
\end{tabular}

Table 9 Heavy metal evaluation index for groundwater at site 7

\begin{tabular}{lllrl}
\hline & Hc & Hmac & Hc/Hmac & HEI \\
\hline $\mathrm{Ni}$ & 0.04 & 0.02 & 2.18 & 33.06 \\
$\mathrm{~Pb}$ & 0.27 & 0.01 & 27.30 & \\
$\mathrm{Fe}$ & 0.63 & 0.3 & 2.11 & \\
$\mathrm{Mn}$ & 0.06 & 0.1 & 0.61 & \\
$\mathrm{Cr}$ & 0.04 & 0.05 & 0.84 & \\
\hline
\end{tabular}

Table 10 Heavy metal evaluation index for groundwater at site 8

\begin{tabular}{lllll}
\hline & $\mathrm{Hc}$ & Hmac & Hc/Hmac & HEI \\
\hline $\mathrm{Ni}$ & 0.01 & 0.02 & 0.80 & 9.68 \\
$\mathrm{~Pb}$ & 0.07 & 0.01 & 7.98 & \\
$\mathrm{Fe}$ & 0.17 & 0.3 & 0.58 & \\
$\mathrm{Mn}$ & 0.01 & 0.1 & 0.14 & \\
$\mathrm{Cr}$ & 0.007 & 0.05 & 0.15 & \\
\hline
\end{tabular}


of HEI values, we can conclude that fly ash disposal in an unlined ash pond has a significant effect on groundwater quality degradation. It is necessary to maintain ash pond in strict agreement with corresponding regulations.

Acknowledgements We would like to gratefully acknowledge the Environmental Engineering Laboratory in Civil Engineering Department of Gautam Buddha University.

Funding This study was not funded by any organization or institution.

\section{Declarations}

Conflicts of interest The authors declare that they have no conflicts of interest.

Open Access This article is licensed under a Creative Commons Attribution 4.0 International License, which permits use, sharing, adaptation, distribution and reproduction in any medium or format, as long as you give appropriate credit to the original author(s) and the source, provide a link to the Creative Commons licence, and indicate if changes were made. The images or other third party material in this article are included in the article's Creative Commons licence, unless indicated otherwise in a credit line to the material. If material is not included in the article's Creative Commons licence and your intended use is not permitted by statutory regulation or exceeds the permitted use, you will need to obtain permission directly from the copyright holder. To view a copy of this licence, visit http://creativecommons.org/licenses/by/4.0/.

\section{References}

American Public Health Association (APHA) (2005) Standard methods for the examination of water and waste water, 21st edn. American Public Health Association, Washington

Baba A, Kaya A, Birsoy YK (2003) The effect of Yatagan thermal power plant (Mugla Turkey) on the quality of surface and ground waters. Water, Air Soil Poll 149:93-111
Bureau of Indian Standard (BIS) (2012) Drinking water specificationIndian Standard: IS 10500, second revision

Carlson CL, Adriano DC (1993) Environmental impacts of coal combustion residues. J Environ Qual 22:227-247

Chanchal MS, Hussain A (2014) Groundwater contamination due to fly ash disposal: a review. Int J Adv Res Bio Sci 1(6):237-250

Choi SK, Lee S, Song YK, Moon HS (2002) Leaching characteristics of selected Korean fly ashes and its implications for the groundwater composition near the ash disposal mound. Fuel 81:1083-1090

Edet AE, Offiong OE (2002) Evaluation of water quality pollution indices for heavy metal contamination monitoring: a study case from Akpabuyo-Odukpani area, lower cross river basin (South Eastern Nigeria). Geo J 57:295-304

Goodarzi F (2006) Characteristics and composition of fly ash from Canadian coal fired power plants. Fuel 85:1418-1427

Kapoor S, Christian RA (2016) Transport of toxic elements through leaching in and around ash disposal sites. Int J Environ Sci Dev 7(1):65-68

Kim AG, Kazonich G, Dahlberg M (2003) Relative solubility of cations in class F fly ash. Environ Sci Technol 37(19):4507-4511

Mandal A, Sengupta D (2005) Radionuclide and trace element contamination around Kolaghat Thermal Power Station. West BengalEnviron Impl Curr Sci 88(4):617-624

Mudd GM, Weaver TR, Kodikara J, Mckinley T (1998) Groundwater chemistry of the Latrobe valley influenced by coal ash disposal-1: dissimilatory sulphate reduction and acid buffering. In: Int. 1 Association of conference: groundwater sustainable solutions, Melbourne, VIC, Feb

Praharaj T, Powell MA, Hart BR, Tripathy S (2002) Leachability of elements from sub-bituminous coal fly ash from India. Environ Int 27:609-615

Singh RK, Gupta NC, Guha BK (2014) pH dependence leaching characteristics of selected metals from coal fly ash and its impact on groundwater quality. Int J Chem Environ Eng 5(4):218-222

Theis TL, Gardner HK (1990) Environmental assessment of ash disposal. Crit Rev Environ Control 20:21-42

Publisher's Note Springer Nature remains neutral with regard to jurisdictional claims in published maps and institutional affiliations. 